\title{
Down Regulated Protein C Plasma Levels in the Absence of Factor $V$ Leiden Mutation in HIV Patients: An Observational Study in Maiduguri, North-Eastern Nigeria
}

\author{
Simon 0. Obi ${ }^{1}$, Ballah Akawu Denue ${ }^{2 *}$, Ifeanyi Chukwu 0. Martin³, Marycelin M. Baba1, \\ Grace I. Amilo" ${ }^{4}$, Salihu Aliyu Kwayabura5, Obi Ejeatulu ${ }^{6}$ \\ ${ }^{1}$ Department of Medical Lab, Science College of Medicine, University of Maiduguri, Maiduguri, Nigeria \\ ${ }^{2}$ Department of Medicine, University of Maiduguri Teaching Hospital, Maiduguri, Nigeria \\ ${ }^{3}$ Department of Immunology, Faculty of Medicine, Nnamdi Azikiwe University, Awka, Nigeria \\ ${ }^{4}$ Department of Haematology, Faculty of Medicine, Nnamdi Azikiwe University, Awka, Nigeria \\ ${ }^{5}$ Department of Obstetrics and Gynaecology, University of Maiduguri Teaching Hospital, Maiduguri, Nigeria \\ ${ }^{6}$ Department of Pharmacology, Faculty of Medicine, Nnamdi Azikiwe University, Awka, Nigeria \\ Email: ${ }^{*}$ d_akawu@yahoo.co.uk
}

Received 17 February 2015; accepted 23 May 2015; published 28 May 2015

Copyright (C) 2015 by authors and Scientific Research Publishing Inc.

This work is licensed under the Creative Commons Attribution International License (CC BY).

http://creativecommons.org/licenses/by/4.0/

(c) (i) Open Access

\section{Abstract}

Background: As life expectancy of HIV-infected patients increases with use of highly active antiretroviral therapy (HAART), protean haematologic manifestation including decreased activity of natural anticoagulants such as protein $\mathrm{C}$ may occur in the absence of genetic risk factors. Based on this preposition, we assessed the plasma level of protein $C$, and prevalence of factor $V$ Leiden mutation among HIV-infected individuals. Our cohort consisted of $499 \mathrm{HIV}$-infected patients, of which 250 had AIDS, while 249 were either asymptomatic or had minor muco-cutaneous infection consistent with WHO clinical stages I and II without features of AIDS. We also evaluated 251 healthy, HIV-negative subjects as controls. All participants were tested for plasma protein C levels and factor V Leiden (FVL) mutation (Arg $506 \mathrm{Gln}$ ) by automation and amplification created restriction enzyme site (ACRES) polymerase chain reaction, respectively. The prevalence of reduced protein $C$ plasma levels among HIV positive patients was 20\%; it was more prevalent among those that had AIDS compared with those without features of AIDS, but within WHO clinical stage I and II, $\mathbf{9 3 . 3 \%}$ vs $6.7 \%$ ) respectively. None of the control patients had either reduced protein C nor FVL mutation. All participants that demonstrated reduced protein $\mathrm{C}$ plasma levels demonstrated normal FVL genotype (1691G/G). Conclusion: Decreased protein C plasma levels can occur in HIV-infected pa-

\footnotetext{
"Corresponding author.
}

How to cite this paper: Obi, S.O., et al. (2015) Down Regulated Protein C Plasma Levels in the Absence of Factor V Leiden Mutation in HIV Patients: An Observational Study in Maiduguri, North-Eastern Nigeria. World Journal of AIDS, 5, 76-82. 
tients in the absence of factor $V$ Leiden mutation. The risk increases with severity of the disease. Deranged protein $C$ plasma level increases the risk of hypercoagulable state in patients with advanced HIV disease; it should be considered among the causes of thrombo embolism in this group of patients.

\section{Keywords}

\section{HIV Infection, Protein C, Factor V Leiden Mutation}

\section{Introduction}

As human immunodeficiency virus (HIV) infection becomes chronic condition due to the successful prolongation of life expectancy among patients treated with highly active antiretroviral therapy (HAART), protean haematologic manifestation including decreased activities of some natural anticoagulant glycoproteins such as protein C (PC) may occur [1] [2]. This phenomenon is related to HIV-associated hypercoagulability [3] [4]. The activation of protein $\mathrm{C}$, a vitamin $\mathrm{K}$ dependendent glycoprotein is enhanced approximately 1000 -fold by thrombin when it binds to thrombomodulin on the endothelial phospholipid surface of blood vessels [5]. This binding blocks the ability of thrombin to catalyze fibrin formation. Activated protein C (APC) functions by inactivating activated factor V (FVa) through cleavage of argenine (Arg 506). This is the site of factor V Leiden (FVL) (Arg 506 Gln) mutation which induces resistance to activated protein C [6] [7]. Activated protein C requires protein $\mathrm{S}$ as a co-factor. The FVL mutation slows down the inactivation of factor Va by APC in addition to degradation of factor VIII a [5] [7]. FVL mutation is recognized as the most common cause of inherited thrombophilia, resulting from decreased degradation by activated protein C [8].

Acquired protein $\mathrm{C}$ dysfunction has been reported among patients with vitamin $\mathrm{K}$ deficiency, use of vitamin $\mathrm{K}$ antagonists, those with liver disease or among those with rare mutation in the gamma glutamyl carboxylase gene [5]. In HIV infection, various pathophysiological mechanisms have been proposed to explain protein $\mathrm{C}$ down regulation. Klein et al., asserted that the presence of antiphospholipid antibodies such as anticardiolipin or lupus anticoagulant and their co-factor $\beta_{2}$ glycoprotein 1 can inhibit the action of APC by interference in its activation pathway [2]. Antiphospholipid anti-bodies have been shown to be present in $82 \%$ - 92\% of HIV infected patients [9]-[11]. It was also observed that inflammatory cytokines such as tissue necrosis factor alpha (TNF $\alpha$ ) released in chronic HIV disease may lead to down regulation of natural anticoagulants such as protein $\mathrm{C}$ and protein S [12]. Of all the natural anticoagulant pathways, protein C appears to be most affected by inflammatory responses [13] [14]. Immune activation and increased apoptosis of T cells, as seen in HIV-infection generates micro-particles which may bind protein S (a co factor to PC) rendering it inactive [15].

This study was therefore undertaken to assess plasma level of functional protein C in HIV-infected individuals in the absence of factor $\mathrm{V}$ Leiden mutation. This may represent a possible cause of the hypercoagulable state seen among HIV-infected patients.

\section{Materials and Methods}

\subsection{Study Area}

This prospective cohort study was conducted between October 2012 and August 2014 among HIV-positive subjects seen in University of Maiduguri teaching hospital (UMTH), Borno State, Nigeria. UMTH is located at the edge of the Sahara desert, it is a 560 bed tertiary health facility which houses a major HIV care and support centre, National poliomyelitis laboratory, Avian flue centre and a National blood transfusion service (NBTS) centre. It is designated a centre of excellence in immunology and infectious diseases.

\subsection{Study Population}

The study population was composed of 499 HIV-infected patients that were divided into two group: (GI) a cohort of 250 asymptomatic patients or those with minor mucocutaneous infections (WHO clinical stage I and II) who were HAART ineligible by WHO criteria [16]; and, (GII) 249 HAART-exposed patients in WHO clinical 
stage IV, with features of AIDS [17]. Additionally, 251 HIV-negative clients (CI) were included as controls. Informed consent and pre-test counselling were instituted before the commencement of the study. Exclusion criteria included: immobility, pregnancy, clinical evidence of active thrombosis, use of tobacco, anticoagulant drugs, hormones or contraceptives. Demographic data were obtained through a semi-structured questionnaire and laboratory records. Ethical clearance was obtained from the research and ethics committee of UMTH.

\subsection{Sample Collection}

Ten millilitres $(10 \mathrm{ml})$ of venous blood was collected aseptically from an arm vein of each subject; $2 \mathrm{ml}$ was dispensed into EDTA specimen bottle for CD4+ T cell counts and FVL mutation molecular analysis. Four and half millilitres $(4.5 \mathrm{ml})$ of blood was dispensed into a plastic bottle containing $0.5 \mathrm{ml}$ sodium citrate $(0.11 \mathrm{molar}$ solution) to give a blood/citrate ratio of 9:1. Platelet poor plasma was separated after centrifugation at $3000 \mathrm{~g}$ and immediately used for functional protein C assay. Three and half millilitres ( $3.5 \mathrm{ml}$ ) was allowed to clot in a plain specimen bottle and serum was used for HIV screening and confirmation tests.

\subsection{Laboratory Analysis}

HIV screening was carried out using immuno-chromatographic reagent kits (Chembio HIV 1 and 2 STAT-PAK from Chembio diagnostic system Inc, Med ford, New York, USA). Positive screening tests were further confirmed by Western Blotting (Qualicode ${ }^{\mathrm{TM}} \mathrm{HIV} 1$ and 2 kit from Immunetics Inc. Boston USA).

CD4+ cell counts were performed with Partec cyflow SL3 using CD4 easy count kit code. MOS-8401; both acquired from (PARTEC GMbH Am Flugp H2. Germany). EDTA blood sample was used.

\subsection{Functional Protein C Assay}

Protein C was estimated as quantitative functional glycoprotein using chromogenic Berichrom protein C kit from Siemens Health care diagnostic product GmbH Germany) Ref. OUVVIS. Internal quality control was achieved using normal control plasma N (Ref. ORKE) and pathological range control plasma P (Ref. OUP2). Result was expressed as \% activity of standard human plasma (Re ORKV) with $70 \%$ - 140\% activity accepted as normal. [17]-[19]. Estimation was carried out with automated coagulometer sysmex CA 560, S/N 1061 (Sysmex Corporation, Kobe-Japan) [20].

\subsection{Factor V Leiden (FVL) (Arg 506 GIn) Mutation Assay}

DNA product extracted from frozen EDTA blood sample was subjected to Amplification Created Restriction Enzyme Site (ACRES) Polymerase Chain Reaction PCR-using forward primer ('5GTAAGAGCAGATCCCTGGACAGtC3'-) in the FVL gene with low cast deliberate mismatch and a reversed primer (5TGTTATCACACACTGGTGCTAA3') without a mismatch. PCR product was subjected to agarose gel electrophoresis. The procedure was carryout at Safety Molecular Pathology Laboratory (www.safetybiomedical.org) at the University of Nigeria, Enugu Campus, (UNEC) Enugu, State Nigeria.

\subsection{Data Analysis}

Statistical package for social science (SPSS) for windows version 20 was used for data analysis. Data was presented as means $(\times)$ and standard deviation (SD). Comparison between variables was achieved by one way ANOVA and post hoc. P-value less than 0.05 at $95 \%$ confidence interval was considered as significant.

\section{Results}

A total of 499 patients were included this prospective study, and they were divided into two groups. The HAART naive cohort, group (GI) (i.e. asymptomatic or had minor muco cutaneous infection) consisted of 249 patients with a gender distribution of 167 (67.1\%) males and 82 (32.9\%) females. Group II (GII) consisted of 250 participants with AIDS of whom 150 were males (60\%) and 100 were females (40\%). The 251 control participants (CI), were made up of 168 (66.9\%) males and 82 (32.1\%) females. The mean age of the participants was similar across groups, and approximately half of the participants were single, with one third being married as shown in Table 1. 
Taking into consideration the mean \pm SD of the studied population, as expected the CD4+ cell Count of controls was higher at $504.12 \pm 213.89$ cells/ul compared with of HIV-infected cohort. The mean CD4+ cell count of participants with AIDS (GII) was lower than that of patients in GI, $212.0 \pm 49.29$ versus $333.11 \pm 91.97$ cells/ul respectively. Correspondingly, the mean values of Protein $\mathrm{C}$ percentage activity was significantly higher among controls compared to that of HIV-infected subjects $(\mathrm{P}<0.05)$. The Protein $\mathrm{C} \%$ mean activity was more efficient (GI) than AIDS (GII) (P<0.05), as depicted in Table 2.

Table 3 shows Protein C \% activity and mean CD4+ cell count values in HIV-infected cohort with CD4 counts $<200$ cells/ $\mu \mathrm{l}$ and their FVL genotype. One hundred and eighteen (118) HIV sero-positive subjects had CD4+ T cell counts $<200$ cells/ $\mu$ l. Those that were asymptomatic or had minor muco cutaneous infection (GI), had CD4+ cell count $<200$ cells/ $\mu l$ in 15 (12.7\%) compared with 103 (87.3\%) in AIDS participants (GII) The mean \pm SD CD4+ cell counts of $184.31 \pm 11.02$ and range (172 - 194) among (GI) compared with $167.56 \pm$ 16.04 and range (150 - 183) among AIDS patients (GII) respectively. Ninety (90) HIV positive patients had CD4+ cell counts $<200$ cells/ $\mu$ l. Of the 118 HIV-positive patients with CD4+ cell count $<200$ cells/ $\mu l, 90$ (76.3\%) had deranged protein C \% activity. Six (6.6\%) were among the GI group with Protein C mean value of $67.37 \pm 0.95$ and range (65\% - 72\%); while $84(93.3 \%)$ of those in GII, had deranged PC \% activity with mean a value of $61.4 \% \pm 2.16 \%$ and range (63\% - 68\%). All the HIV-seropositive subjects (90) with deranged plasma protein C levels had normal FVL genotypes (1691G/G) as depicted in Table 3.

Table 1. Socio demographic characteristics of the studied participants.

\begin{tabular}{cccc}
\hline Variables & Controls (CI) & HAART naive (GI) & On HAART (GII) \\
Sex & $168(66.9 \%)$ & $167(67.1 \%)$ & $150(60.0 \%)$ \\
Males & $83(33.1 \%)$ & $82(32.9 \%)$ & $100(40.0 \%)$ \\
Female & $251(100 \%)$ & $249(100 \%)$ & $250(100 \%)$ \\
Total & & & $36.16 \pm 13.81$ \\
Age (years) & $35.98 \pm 11.75$ & $35.25 \pm 13.10$ & 34 \\
Mean \pm (SD) & 34 & 34 & $138(55.2 \%)$ \\
Median & $134(53.4 \%)$ & $127(51.0 \%)$ & $92(36.8 \%)$ \\
Marital Status & $80(31.9 \%)$ & $83(33.4 \%)$ & $4(1.6 \%)$ \\
Single/never & $7(2.8 \%)$ & $9(3.6 \%)$ & $16(6.4 \%)$ \\
Married & $30(11.9 \%)$ & $30(12.0 \%)$ & $250(100 \%)$ \\
Divorced & $251(100 \%)$ & $249(100 \%)$ & \\
Widow/widower & & & $34 \%$ \\
Total & &
\end{tabular}

Table 2. Mean \pm (SD) of protein C (PC) \% Activity, mean CD4+ counts among studied participants. Variable Mean \pm SD, (PC\%) Mean \pm SD, CD4 count (cells/ul).

\begin{tabular}{ccc}
\hline Controls (CI) & $94.22 \pm 13.50$ & $504.12 \pm 213.89$ \\
HAART naive (GI) & $80.87 \pm 14.19$ & $333.11 \pm 91.97$ \\
On HAART (GII) & $71.66 \pm 6.90$ & $212.0 \pm 49.29$ \\
F statistics & 65.70 & 283.65 \\
P value & $0.01^{* *}$ & $0.001^{* *}$ \\
CI vs GI P value & $0.01^{*}$ & $0.001^{* *}$ \\
CI vs GII p value & $0.001^{* *}$ & $0.000^{* * *}$ \\
GI vs GII P value & $0.01^{*}$ & $0.01^{*}$ \\
\hline
\end{tabular}

Key: P Value ${ }^{*}=0.05,{ }^{* *}=0.01,{ }^{* * *}=0.001$. 
Table 3. Mean \pm SD (range), \% activity of Protein C, and FVL (Arg 506 GLn) genotypes among GI and GII subjects with CD4 counts $<200$ cells/ $\mu$.

\begin{tabular}{cccccc}
\hline Subjects & $\begin{array}{c}\text { Mean } \pm \text { CD4 } \\
\text { (Range) }\end{array}$ & $\begin{array}{c}\text { Frequency } \\
\text { No. }(\%)\end{array}$ & $\begin{array}{c}\text { Mean PC } \\
(\% \text { activity })\end{array}$ & $\begin{array}{c}\text { Frequency } \\
\text { No. (\%) }\end{array}$ & $\begin{array}{c}\text { FVL } \\
\text { Genotype }\end{array}$ \\
\hline $\begin{array}{c}\text { HAART naive } \\
\text { (GI) }\end{array}$ & $184.31 \pm 11.0$ & $15(12.7)$ & $67.37 \pm 0.95$ & $6(6.7)$ & G/G (normal) \\
& $(172-194)$ & $(65-72)$ & & G/G (normal) \\
$\begin{array}{c}\text { On HAART } \\
\text { (GII) }\end{array}$ & $167.56 \pm 10.0$ & $103(87.3)$ & $61.43 \pm 216$ & $84(93.3)$ & \\
& & $(63-68)$ & $90(100)$ & \\
\hline
\end{tabular}

Key: FVL = Factor V Leiden; Arg = Argenine; GLn = Glutamine. GI = HIV infected patients that are asymptomatic or with minor mucocutaneous. Infection i.e. WHO Clinical stage I or II. GII = AIDS patients.

\section{Discussion}

This study revealed a statistically significant difference in the mean protein C (PC) plasma levels in the control subjects compared to the mean values among patients with HIV. Previous studies had reported such observation [21] [22]. Down regulation of the PC was greater in the HAART experienced subjects with features of AIDS than HAART ineligible subjects. Advanced HIV disease and toxicity of antiretroviral drugs are known to be associated with haematological and hepatic impairments [23] [24]. Protein C, a vitamin K dependent glycoprotein is largely synthesized by the liver [24]. Deranged PC plasma level were observed in HIV subjects with CD4 + T cell counts $<200$ cells $/ \mu$ in our study. Deranged protein $\mathrm{C}$ level related to quantitative and qualitative defects in CD4+ cell count in HIV disease had been reported in the literature [7] [11] [21] [22]. The association was more marked among AIDS patients on HAART (93.3\%). Only 6.7\% of the asymptomatic HIV-infected subjects had decreased CD4+cell count and deranged protein C plasma levels, indicating that deranged protein $\mathrm{C}$ activity is more prevalent among those with advanced HIV disease and immunological AIDS (CD4+ cell count $<200$ cells/ $\mu \mathrm{l})$. Worthy of note however is that all the subjects with deranged PC plasma levels in this study expressed normal FVL genotype $(1691 \mathrm{G} / \mathrm{G})$. This in our opinion appears to suggest that the down regulation of plasma level of protein $C$ as seen in this study may be related to qualitative and qualitative defects in immune status, which appears to worsen as immune status diminished. De-visser et al. in a similar study, reported reduced sensitivity for activated protein C in subjects without FVL mutation [25].

Factor V Leiden (Arg 506 Gln) mutation is documented as the most common cause of activated protein C (APC) resistance which can result in deranged protein C functional activity level [25].

Down regulated protein C levels in HIV disease have been associated with increased risk for venous thrombosis [1]-[4] [11]. This risk, which increases with advancing disease is believed to be $2-10$ folds higher in HIV disease compared to healthy population of similar age [11] [25]. Inhibitory effect of antiphospholipid antibodies such as lupus anticoagulant on activation pathway of Protein $\mathrm{C}$ in part has been adduced as one of the viraemic challenges responsible for deranged protein C plasma levels in HIV disease [2]. Stimmiler et al., [9], and Ankri et al., [10] previously observed that antiphospolipid antibodies were present in greater than $70 \%$ of patients chronic HIV disease. Microparticles generated as a result of increased CD4 apoptosis in HIV infection can bind protein S-(a co-factor to protein C)-rendering it inactive [2]. Enhanced immune activation in HIV sero-positive subjects is believed to be another challenge responsible for the initiation of microparticle phenomenon in HIV disease [16]. The influence of increased levels of inflammatory cytokines such as tissue necrosis factor alpha (TNF $\alpha$ ) in chronic HIV disease has also been implicated in the down regulation of natural anticoagulants such as protein C [12] [25].

\section{Conclusion}

Decreased protein C plasma levels can occur in HIV infected patients in the absence of FVL mutation. The risk increases with severity of the disease. Deranged protein C plasma level increases the risk of hypercoagulable state in patients with advanced human immunodeficiency virus, and it should be considered among the causes of thrombo embolism in this group of patients. 


\section{Recommendations}

With the finding of reduced protein C activity in patients with advanced HIV infection, they are at risk of hypercoagulable state. Studies into risk factors-including defects in natural anticoagulant biomarkers which contribute to the balancing mechanism in haemostasis is advocated for comprehensive care of these patients.

\section{References}

[1] Shen, Y.P. and Frankel, E.P. (2004) Thrombosis and Hypercoagulable State in HIV Infected Patients. Clinical and Applied Thrombosis/Hemostasis, 10, 270-280. http://dx.doi.org/10.1177/107602960401000311

[2] Klein, S.K., Slim, E.J., de Kruifde, M.D., Keller, T.T., Ten Cate, H. and Van Gorp, E. (2005) Is Chronic HIV Infection Associated with Venous Thrombotic Disease? A Systematic Review. Netherland Journal of Medicine, 69, 129-136.

[3] Eyal, A. and Vella, M. (2009) HIV and Venous Thrombotic Events. South African Journal of Surgery, 7, 93-95.

[4] Opie, J. (2012) Haematological Complications of HIV Infection. The South African Medical Journal, 102, 465-468.

[5] Walker, I.D. (2005) Inherited Thrombophila. In: Hoffbrand, V., Catovsky, D. and Taddenham, E.G.D., Eds., Postgraduate Hematology, 5th Edition, Wiley India, Blackwell Publishing Ltd., Oxford, 885-889.

[6] Geoffery, K.C., Edward, G.D. and John, H.M. (2005) Protein C Pathway-Inhibition of Co Factors FVa and FVllla. Post Graduate Haematology, 5th Edition, Blackwell Publishing Ltd., Oxford, 802-804.

[7] Dahlback, B. and Vittoutreix, B.O. (2003) Molecular Recognition in the Protein C Anticoagulant Pathway. Journal of Thrombosis and Haemostasis, 1, 1525-1531. http://dx.doi.org/10.1046/j.1538-7836.2003.00299.x

[8] Bauer, K.A. (2003) Management of Thrombophilia. Journal of Thrombosis and Haemostasis, 1, 1429-1434. http://dx.doi.org/10.1046/j.1538-7836.2003.00274.x

[9] Stimmiler, M.M., Quismorio, F.P., McGehee, W.E., Boylan, T. and Sharma, O.P. (1989) Anticardiolipin Antibodies in Acquire Immunode Ficiency Syndrome. Archival international Medicine, 149, 1833-1834. http://dx.doi.org/10.1001/archinte.1989.00390080091020

[10] Ankri, A., Bonmarchand, M., Coutellier, A., Hensons, A. and Karmochkine, M. (1999) Antiphospholipid Antibodies Are Epiphenomenon in HIV Infected Patients. AIDS, 13, 1282-1283. http://dx.doi.org/10.1097/00002030-199907090-00024

[11] Bibas, M., Gianluigi, B. and Andrea, A. (2011) HIV Associated Venous Thomboembolism. Mediterrenian Journal of Hematology and Infectious Disease, 3, 2035-3006. http://dx.doi.org/10.4084/mjhid

[12] Hooper, G., Philip, J. and Robeiro, A. (1994) Tumor Necrosis Factor-Alpha down Regulates Protein S Secretion in Human Micro Vascular and Umblical Vein Endothehal Cells. Hep G2 Hepatoma Cell Line. Blood, 84, 483-489.

[13] Esmon, C.T. (2000) The Endothelial Cell Protein C Receptor. Thrombosis and Haemostasis, 83, 639-643.

[14] Beverly, J. (2005) Hunt and Michael Greave. Acquired Venous Thrombosis. Postgraduate Haematology, 5th Edition, Black Well Publishing, Oxford, 905.

[15] Javier, C. (2007) Immune Activation and Increased Prevalence of Thrombosis in HIV Infection. Journal of AIDS, 46, 375-376. http://dx.doi.org/10.1097/qai.0b013e31813eb7f6

[16] World Health Organisation (2007) WHO Case Definitions of HIV for Surveillance and Revised Clinical Staging and Immunological Classification of HIV-Related Disease in Adults and Children. World Health Organisation.

[17] (1993) Revised Classification System for HIV Infection and Expanded Surveillance Case Definition for AIDS among Adolescents and Adults.

[18] Kraus, M., Protein, C. and Protein, S. (1998) Factor V Leiden. In: Thomas, L., Ed., Clinical Laboratory Diagnostics Franktar. TH Book Verlag, Frankfurt, 621-625.

[19] CLSI (2008) Collection, Transport, and Processing of Blood Specimen for Testing Plasma Based Coagulation Assay and Molecular Hemostasis Assay. Approved Guide Line 5th Edition CLSI Document H21-A5.

[20] Siemens Healthcare Diagnostic Products (2008) Berichrom Protein C Reagent Kit, Procedure Manual OUVVG15 E0502 (194) CS/ST.

[21] Erbe, M., Richerts, V., Bauesacha, M. and Lindhood, E. (2003) Acquired Protein C and Protein S Deficiencies in HIV Infected Patients. Clinical and Applied Thrombosis and Haemostasis, 9, 325-331. http://dx.doi.org/10.1177/107602960300900408

[22] Katie, K. and Melissa, B. (2011) Risk Factors for Venous Thromboembolism in Patients with HIV-Infection. Pharmacotherapy, 30, 1293-1304.

[23] Christine, C. (2005) Haematology in HIV Disease. Postgraduate Haematology, 5th Edition, Blackwell Publishing Ltd., 
Oxford, 381-394.

[24] Mayne, P.D. (2005) Liver and Gallstones in Clinical Chemistry in Diagnosis and Treatment. 6th Edition, India Book Power (Formerly ELST), 283-284.

[25] De Visser, M.C., Rosendaal, F.R. and Bertina, R.M. (1999) A Reduced Sensitivity for Activated Protein C in the Absence of Factor V Leiden Increases the Risk of Venous Thrombosis. Blood, 93, 1271-1276. 